Omni-Akuatika, 14 (2) : 11 - 20, 2018
ISSN: 1858-3873 print / 2476-9347 online
Research Article
journal homepage: http://ojs.omniakuatika.net

\title{
Bioremediation of Indigosol Blue 04B Batik Effluent by Indigenous Fungal Isolates, Aspergillus spp.
}

\author{
Ratna Stia Dewi ${ }^{1,4^{*}}$, Rina Sri Kasiamdari ${ }^{2}$, Erni Martani ${ }^{3}$, Yekti Asih Purwestri ${ }^{2}$ \\ ${ }^{1}$ Post-graduate student, Faculty of Biology, Universitas Gadjah Mada, Yogyakarta, Indonesia \\ ${ }^{2}$ Faculty of Biology, Universitas Gadjah Mada, Yogyakarta, Indonesia \\ ${ }^{3}$ Agriculture Microbiology, Faculty of Agriculture, Universitas Gadjah Mada Yogyakarta, Indonesia \\ ${ }^{4}$ Faculty of Biology, Universitas Jenderal Soedirman, Purwokerto, Central Java, Indonesia
}

* ${ }^{*}$ Corresponding author:: ratna_stiadewi@yahoo.co.id

\begin{abstract}
Effluent from the local batik home industry is a serious problem, because the effluent discharge generated is spread in different places. Untreated effluent can cause environmental pollution, such as in groundwater reservoirs, because most is discharged into rivers. The aim of this research was to evaluate the bioremediation potential of indigenous fungi in liquid culture media with Indigosol Blue 04B (IB) batik effluent. The fungi isolates tested were Aspergillus sp. 1, Aspergillus sp. 2 and Aspergillus sp. 3, isolated from dye effluent soil and batik effluent, and compared to white rot fungi (Phanerochaete chrysosporium) as a positive control. The physiochemical properties of IB batik effluent before and after fungal treatment were investigated. All of these parameters before the fungal treatment were above the recommended standard values based on the Governor regulation of Yogyakarta Special Region No. 7/2010. The level of biochemical oxygen demand (BOD), chemical oxygen demand (COD), total dissolved solids (TDS), total suspended solids (TSS), and electrical conductance (EC) was reduce by Aspergillus spp. The highest percentage reduction was achieved by Aspergillus sp. 3, namely $88.34 \%$ BOD, $89.11 \%$ COD, $75.77 \%$ TSS, $85.85 \%$ TDS and $71.21 \%$ EC, after 3 days of incubation. These results show that the positive control isolate had the lowest value. The study confirms the ability of indigenous fungi isolates in the remediation of IB batik effluent and their potential for future analysis in the treatment of all types of batik effluent.
\end{abstract}

Keywords : Bioremediation, Indigosol, Batik Effluent, Aspergillus spp., physiochemical.

\section{Introduction}

One source of local revenue in Banyumas Regency comes from the batik industry. Banyumas batik consists of several home industries incorporating groups of batik craftsmen. Besides having positive impacts on the region, the industry also has negative ones. One problem is centered on the the absence of effluent treatment installations to treat the waste. Therefore, the batik craftsmen dispose ofthe effluent directly into rivers near the production site. This discharged waste contains pollutants with very high levels of organic materials, causing color change in the river water.

The environmental capability of rivers to accommodate the pollutants is limited and eventually damage can be caused to the environment it self. The various chemical agents used in the dyeing process can be harmful to aquatic life,notably when the effluent is released without any prior treatment (Kusumastuti and Syamwil, 2014). The presence of effluent in rivers threatens fishlife and other aquatic biota, and causes environmental pollution (Arimoro et al., 2007 and Velz, 1985). Environmental pollution caused by the level of effluent discharged into water bodies does not meet the maximum permissible quality standard limits for batik industry activity set by the Governor regulation of Yogyakarta Special Region No. 7/2010. Nindita et al. (2012) found that production of 40 pieces of batik cloth produces about 202.4 I of dye effluent. Only $0.6 \%$ of this is used during the dyeing, while the remainder is directly discharged without any prior treatment (Fajri, 2013).

The batik industry produces effluent from the process of dyeing or immersion. It should be noted that not all types of dye can be used in 
batik techniques, as batik dyeing is done without heating, as it uses wax, which is not heat-resistant. The use of wax is to allow the batik pattern to form perfectly. Batik wax will be melted at high temperatures. Synthetic dyes that can be used in batik processing include vat dyes (Sunarto, 2008; Kusumastuti \& Syamwil, 2014). Indigosol colours are solubilized vat dyes (cKinetics, 2018), with Indigosol belonging to the type ofvat dye which is derived from the indigo complex (Jagson Colorchem Ltd, 2011). Indigosol batik waste comprises Indigosol dye powder, sodium nitrite and hydrochloric acid (Budiyonoet al., 2008). About 5\% of the 60, 000 tons/year world consumption ofdyes is Indigo dye (Paradise, 1999; Spadaro et al., 1994), with annual production of this dye estimated at 22,000 tons (Schrott, 2001). The very high level of use use is responsible for wastewater. According to Balan and Monteiro (2001), Indigo dyes are considered as recalcitrant substances that cause environmental damage. Therefore, it is necessary to conduct a degradation process before discharging them into the environment.

Effluent from dye processing causes serious environmental problems. The use of these chemicals can increase BOD and COD in water resources (Rashidi et al., 2012). Laboratory test results show that the quality of river water contaminated by batik effluent does not meet the quality standards for batik effluent set by government regulations, especially the textile effluent quality standards TDS, TSS, EC $\mathrm{NH}$, sulfide, chrome total $(\mathrm{Cr})$, phenols, oils and fats. The BOD value was $869 \mathrm{mg} / \mathrm{l}$ and the COD value2200 mg/l (Aryani et al., 2004).

Efforts made to overcome the negative impact of pollution of from batik industry effluents include treatment before their discharge into rivers. Fungal bioremediation is one of the most effective ofthe various water treatment technologies, being an easy to implement and economical effluent treatment alternative. However, the biomass produced during the effluent treatment by fungi is of a much higher value than that fromthe bacterial process (Sankaran et al., 2010). Bioremediation by fungi compared with bacteria has been shown to be significantly higher for the degradation of synthetic dyes (Shahid et al., 2013). Fungi have been proven to be the most effective organism for textile waste treatment and decolorization. Fungi have more advantages compared single cell organisms because their mycelia can dissolve insoluble substrates by producing extracellular enzymes. Fungi have greater physical and enzymatic contact with the environment because of their ratio to the cell surface (Kaushik \& Malik, 2009).
Based on previous research, white-rot fungus Phanerochaete chrysosporium is an ideal model for bioremediation by fungi, since it is more efficient than other fungi or microorganisms in degrading toxic or insoluble materials (Rhodes, 2014). P. chrysosporium URM 6181 has proven to be effective in the treatment of textile effluent. Effluent treated by $P$. chrysosporium URM 6181 accumulated a mutagenic metabolite derived from indigo dye (Rita de Cássia et al., 2013).

P. chrysosporiumURM 6181 has proven to be effective in the treatment of textile effluent. Effluent treated by $P$. chrysosporium URM 6181 accumulated a mutagenic metabolite derived from indigo dye (Rita de Cássia et al., 2013).

In recent years, various studies have been conducted on fungi which are able to biosorp and biodegrade dyes in effluent (Ambrosio and Campos-Takaki, 2004; Eichlerova' et al., 2006). Most bioremediation research using fungi has focused on $P$. chrysosporium, which is known for its ability to degrade a variety of recalcitrant compounds and xenobiotics (Cameron et al., 2000). Other fungi,such as various Aspergillus spp., have been shown to decolorize several dyes. The Aspergillus sojae B10 isolate has shown to decolorize the azo dyes Congo red, amaranth and Sudan III after 3-5 days of incubation in nitrogen-poor media (Ryu and Weon, 1992). Aspergillus oryzae and Aspergillus fumigates G-2-6,capable of decolorizing various structurally different dyes, were isolated and found to be more effective than $P$. chrysosporium (Knapp et al., 1995). The aim of this research is to evaluate the bioremediation potential of indigenous fungi (Aspergillus spp.) in Indigosol Blue 04B (IB) batik effluent.

\section{Materials and Methods}

\section{Samples and Chemicals}

The samples of Indigosol Blue 04B (IB) batik effluent used for the bioremediation in this investigation were collected from several domestic batik effluent discharge drains and kept in a refrigerator at $4^{\circ} \mathrm{C}$. The indigenous fungal isolates used were Aspergillus sp. 1, Aspergillus sp. 2 and Aspergillus sp. 3, isolated from dye effluent soil and batik effluent. One culture of white rot fungus ( $P$. chrysosporium) InaCC F206 from Indonesian Culture Collection (InaCC), Research Center for Biology, Indonesian Institute of Sciences (LIPI) was also used in the study. Media components used 
were Potato Dextrose Agar (PDA) and Potato Dextrose Broth (PDB).

\section{Preparation of Culture Conditions}

The isolates were maintained in a PDA medium at room temperature until utilization, and the characteristics of the microscopic fungi were carried out by the slide culture technique. In this method, $P$. chrysosporium was employed as a positive control and the IB batik effluent was employed as a negative control. A comparison was made between the isolated fungi.

\section{Physiochemical Analysis}

In this work, we only study the reduction in BOD, COD, TDS, TSS, EC, temperature and $\mathrm{pH}$. Wastewater treatment objective were based on the reduction of BOD, TSS, and other parameter (Metcalf \& Eddy, 1991). The temperature and $\mathrm{pH}$ of the effluent samples were measured at the collection site. The BOD, COD, TDS, TSS and EC were analyzed in the laboratory according to the methods prescribed by Indonesian National Standard (abbreviated to SNI), which are the only standards that apply nationally in Indonesia (Salar et al.2012).

\section{IB Batik Effluent Bioremediation.}

One hundred milliliters of PDB medium were transferred to $250 \mathrm{~mL}$ Erlenmeyer flasks. The flasks were inoculated with $2 \%(\mathrm{v} / \mathrm{v})$ fungal spore suspension containing $10^{6}$ CFU and incubated by shaking at temperature room for 3 days. The medium amended with each of the tested IB batik effluents. Control experiments were performed inthe same conditions as described above, but without the fungi.The percentage of physiochemical reduction was calculated by the following equation:

Basic Equation: (treated/untreated Effluent) ${ }^{*} 100$.

\section{Results and Discussion}

IB batik effluent was polluted with organic loads in the form of BOD and COD, and also with dissolved and suspended solids in the formof TSS and TDS (Table 1). The concentrations of BOD, COD, TDS and TSS untreated fungally were very high compared to the maximum permissible effluent limits for the for batik industry activity by the Governor regulation of Yogyakarta Special Region No. 7/2010 regarding effluent level standards for industrial health, health services and tourism services. Theseresults agree with the findings of Rochma and Titah (2017), who obtained values of $B O D, C O D$ and TSS duringthe dyeing process of $1777.5,16654.8$ and $208 \mathrm{mg} \mathrm{L}-1$ respectively. The effluent was treated in amycological operation with three species of fungi. BOD, COD,TDS and TSS concentrations were measured before and after the fungal treatment.

Table 1. Physicochemical analysis of IB batik effluentand permissible limits

\begin{tabular}{lll}
\hline Parameters & $\begin{array}{l}\text { Maximum permissible limits } \\
\text { of Quality Standard }\end{array}$ & Values of effluent \\
\hline Biochemical oxygen demand $(\mathrm{mg} \mathrm{L}-1)$ & 85 & 1470.68 \\
Chemical oxygen demand $\left(\mathrm{mg} \mathrm{L}^{-1}\right)$ & 250 & 15800 \\
Total dissolved solids $\left(\mathrm{mg} \mathrm{L}^{-1}\right)$ & 2000 & 16546.67 \\
Total suspended solids $\left(\mathrm{mg} \mathrm{L}^{-1}\right)$ & 60 & 374.6 \\
Electrical conductance $\left(\mathrm{mS} \mathrm{cm}^{-1}\right)$ & 1.56 & 17.44 \\
Temperature $\left({ }^{\circ} \mathrm{C}\right)$ & $\pm 3^{\circ} \mathrm{C}$ from air temperature & 27 \\
$\mathrm{pH}$ & $6-9$ & 5 \\
\hline
\end{tabular}

\section{Biological Oxygen Demand (BOD)}

$\mathrm{BOD}$ concentration decreased in the IB batik effluent treated with Aspergillus spp. compared to the positive and negative controls (Figure 1). The results show that IB batik effluent treated with indigenous fungal isolates displayed lower BOD value than those observed in the positive control but otherwise on negative control. The results indicate that indigenous fungal isolates were effective in the reduction of BOD from the effluent, even when compared to the positive control that is known to have such capabilities. The reduction of BOD by Aspergillus sp. 1,2,3 ranged from 1470.68 $\mathrm{mg} \mathrm{L}^{-1}$ (negative controls) to $495.48 \mathrm{mg} \mathrm{L}^{-1}$, 1145.48 and 171.48 (fungally treated), respectively. Furthermore, Aspergillus sp. 3 displayed superiorability over the other isolates inreducing BOD.

\section{Chemical Oxygen Demand (COD)}

The results of the average values of $C O D$ in IB batik effluent after treatment with 
Aspergillus spp. are presented in Figure 2. COD concentrations after treatment withAspergillus sp. 1, 2, 3 were $6280 \mathrm{mg} \mathrm{L}-1$, $1720 \mathrm{mg} \mathrm{L}-1$, and $6240 \mathrm{mg} / \mathrm{L}$, respectively. These values show that COD has decreased from the initial characteristics of IB batik effluent (1470.68 mg/l). Figure 2 also shows that Aspergillus sp. 3 has superior qualities in reducing COD concentration.

According to the quality standards of the Governor regulation, the maximum permissible limit of BOD is 85 and that of COD 250. Although its are still above the limit,there is the possibility of reducing the COD value further.

BOD as a measure of the amount of oxygen used by the microbial population contained in water in response to the influx of organic matter that can be decomposed (Mays, 1996). Boyd (1990) stated that the BOD is interpreted as an overview of the amount of biodegradable organic material in water.
Organic material in BOD is readily decomposable organic matter. COD (chemical oxygen demand) is the amount of oxygen required to decompose all the organic matter contained in water. COD describes the total amount of organic matter present in water, which is organic material that is bothdifficult and easy to decompose.

The overall BOD rates shown in Figure 1 decreased after treatment using Aspergillus spp. This means that the amount of organic matter easily decomposed in the untreated effluent (negative control) has decreased. Based on Figure 2, COD levels after treatment using Aspergillus spp decreased. This data shows a decrease in the total amount of organic matter present in untreated wastewater effluent (negative control), both organic materials that are difficult to digest and easy to decompose.

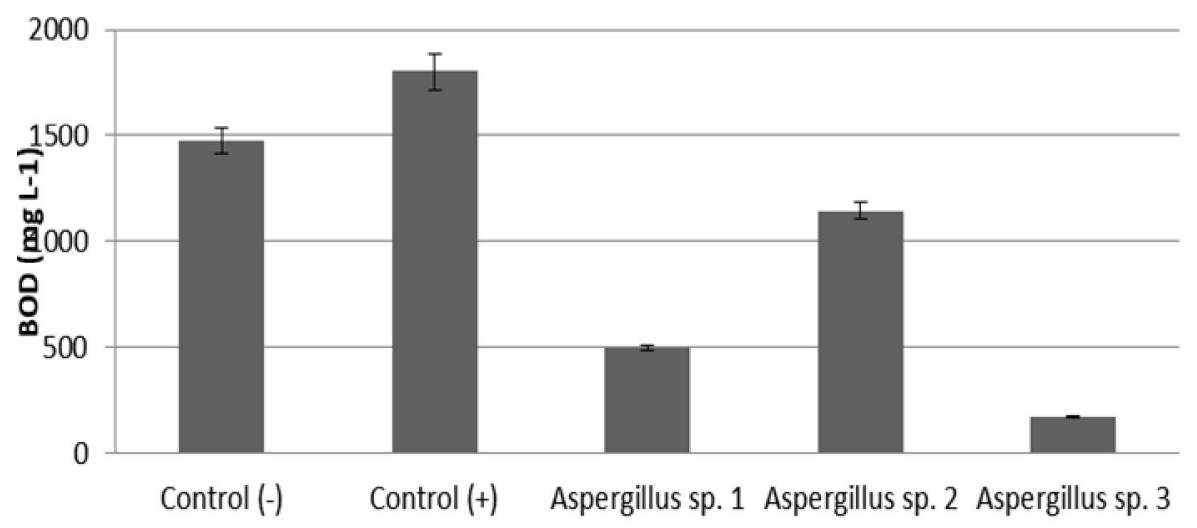

Figure 1. Effect on BOD of different fungal isolates

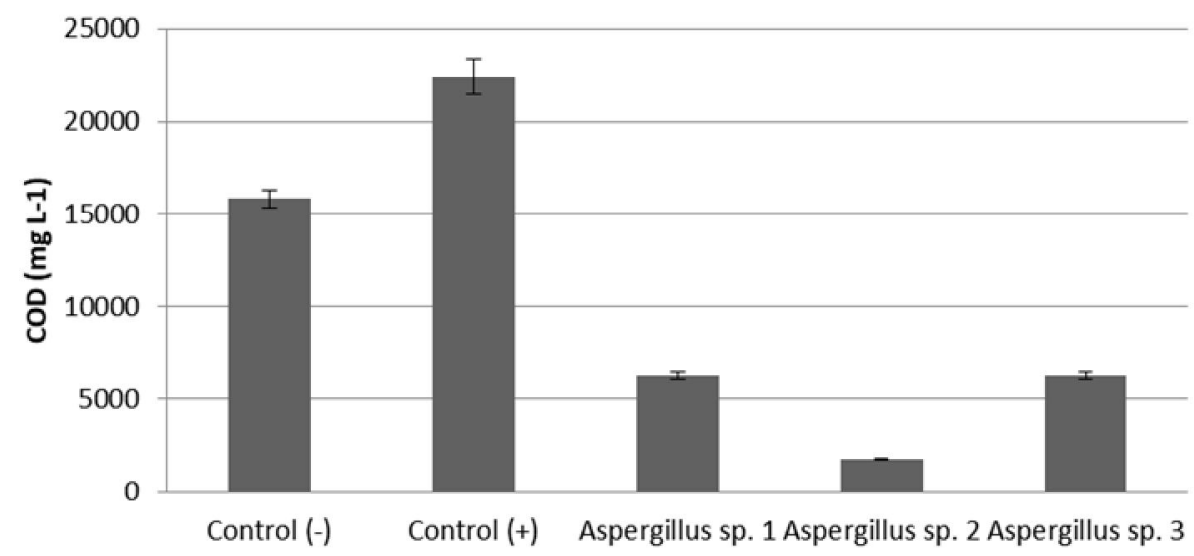

Figure 2. Effect on COD of different fungal isolates 


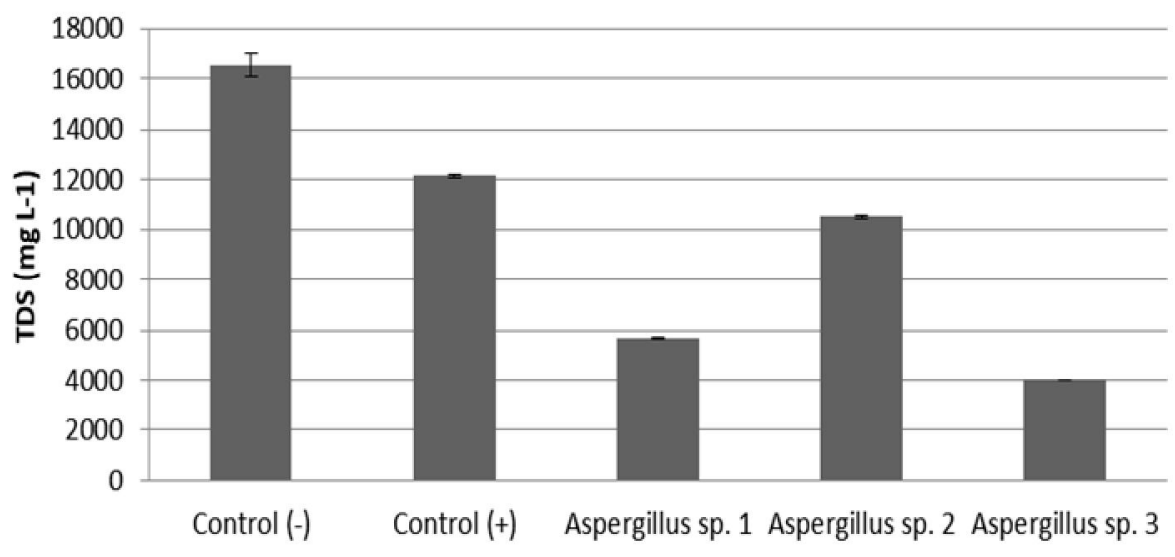

Figure 3. Effect on TDS of different fungal isolates.

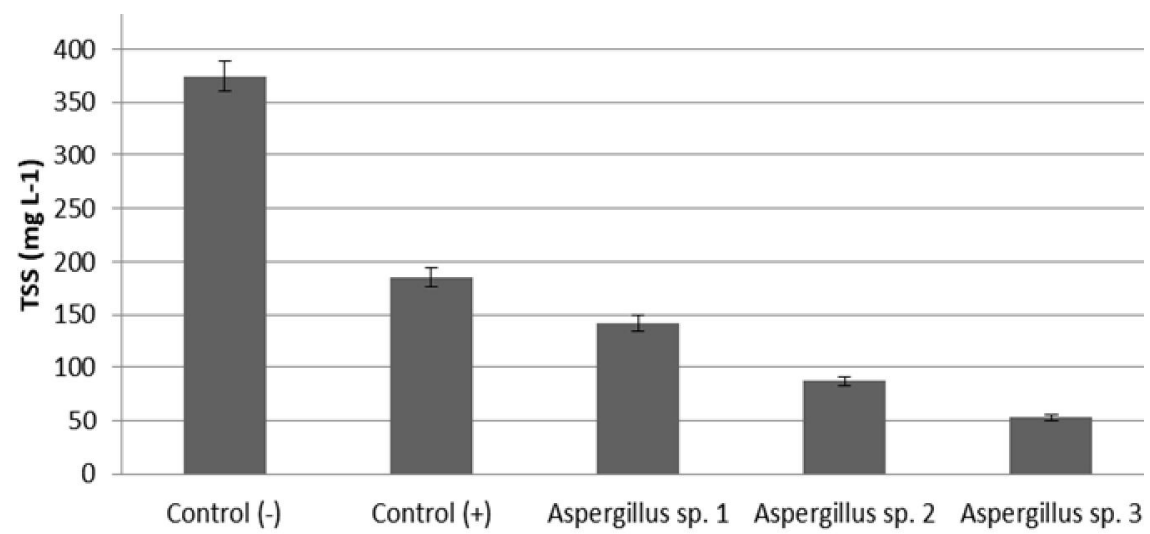

Figure 4. Effect on TSS of different fungal isolates.

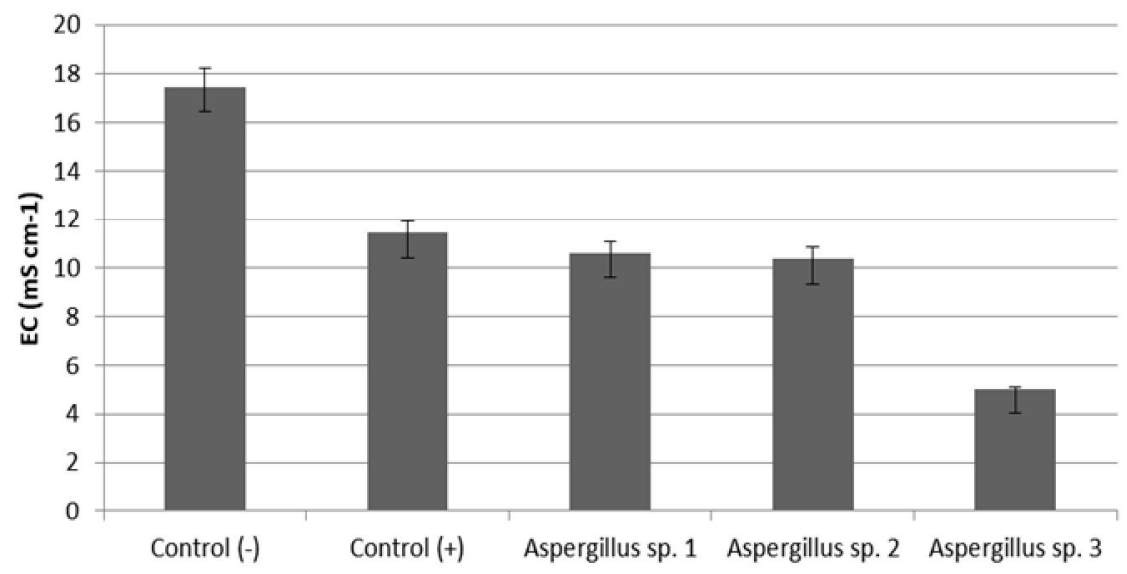

Figure 5. Effect on EC of different fungal isolates. 
Total Dissolved Solids (TDS)

The TDS values from the research are shown in Figure 3. Values of $5673.33 \mathrm{mg} \mathrm{L}-1$, $10493.33 \mathrm{mg} \mathrm{L}-1$, and $4010 \mathrm{mg} \mathrm{L}-1$, for the determination of TDS were obtained after the application of Aspergillus sp. 1, Aspergillus sp.2, and Aspergillus sp. 3 respectively. The TDS values of P.chrysosporium showed lower concentrations compared to the other isolates. Figure 4 also shows thatAspergillus sp. 3 had the highest TDS value. This indicates that Aspergillus sp. 3 was the best isolate for reducing TDS.

\section{Total Suspended Solids (TSS)}

Figure 4 shows good values of 141.8 , 87.2 and $53 \mathrm{mg} \mathrm{L}^{-1}$ for TSS after Aspergillus sp. 1, Aspergillus sp.2, and Aspergillus sp. 3 treatment, respectively. Figure 4 also shows that the TSS values of theindigenous fungal isolates are greater than the TSS values of P.chrysosporium treatment. This indicates that Aspergillus sp. 3 is superior to the other fungi.

\section{Electrical Conductance}

The value of $E C$ of the negative control in the untreated IB batik effluent was $17.44 \mathrm{mS}$ $\mathrm{cm}^{-1}$, while the recommended value according to government regulations is $1.56 \mathrm{mS} \mathrm{cm}^{-1}$. This indicates that the effluent contains heavy metals at a high enough level to conduct an electrical current.
The level of EC clearly decreased in the IB batik effluent after Aspergillus sp. 1, Aspergillus sp.2 and Aspergillus sp. 3 treatments processes $(10.61,10.38$ and $5.02 \mathrm{mS} \mathrm{cm}^{-1}$ ) compared to the P.chrysosporium treatment $\left(11.44 \mathrm{mS} \mathrm{cm}^{-1}\right.$ ) (Figure 5). It can be said that P.chrysosporium treatment contains heavy metals at a relatively higher level than when using Aspergillus spp. The percentage of EC decrease is shown in Figure 7. The decrease in the level of EC could be due to the decomposition of some heavy metal compounds in the effluent following the fungal treatment.

\section{Temperature Measurements}

The growth of fungi is affected by temperature, with an optimum temperature of $25-30^{\circ} \mathrm{C}$. The temperature of the IB batik effluent was $27.1^{\circ} \mathrm{C} \quad \pm 0.1^{\circ} \mathrm{C} \quad$ (Table 2). According to the quality standards of the Governor regulation, the maximum permissible temperature is air temperature $\pm 3{ }^{\circ} \mathrm{C}$. This indicates that the temperature of the fungal isolate treatment was within the standard range.

pH Measurements

Initial $\mathrm{pH}$ in the negative control (7.5 \pm 0.1.) decreased after treatment by Aspergillus sp. 1, Aspergillus sp.2, and Aspergillus sp. 3, $6.2 \pm 0.2,6 \pm 0.02$ and $6 \pm 0.1$, respectively, while the treatment with $P$. chrysosporium also showed a decrease in initial $\mathrm{pH}, 6.9 \pm 0.1$ (Table 3). 
Table 2. Results of temperature measurements on IB batik effluent [Control (-)],P.chrysosporium $[$ Control $(+)]$ and fungal isolate treatment.

\begin{tabular}{llllll}
\hline Replication & Control (-) & Control (+) & Aspergillus sp. 1 & Aspergillus sp. 2 & Aspergillus sp. 3 \\
\hline 1 & 27.1 & 25.7 & 25.9 & 25.6 & 26 \\
2 & 27.2 & 25.6 & 26 & 25.7 & 26 \\
3 & 27.3 & 25.5 & 26.1 & 25.6 & 26.1 \\
\hline
\end{tabular}

Table 3. Results of $\mathrm{pH}$ measurements on IB batik effluent [Control (-)],[Control (+)] and fungal isolate treatment.

\begin{tabular}{llllll}
\hline Replication & Control (-) & Control (+) & Aspergillus sp. 1 & Aspergillus sp. 2 & Aspergillus sp. 3 \\
\hline 1 & 7.5 & 6.9 & 6.2 & 6 & 6.1 \\
2 & 7.4 & 6.8 & 5.9 & 5.9 & 6.1 \\
3 & 7.3 & 6.7 & 5.8 & 6.1 & 6.15 \\
\hline
\end{tabular}

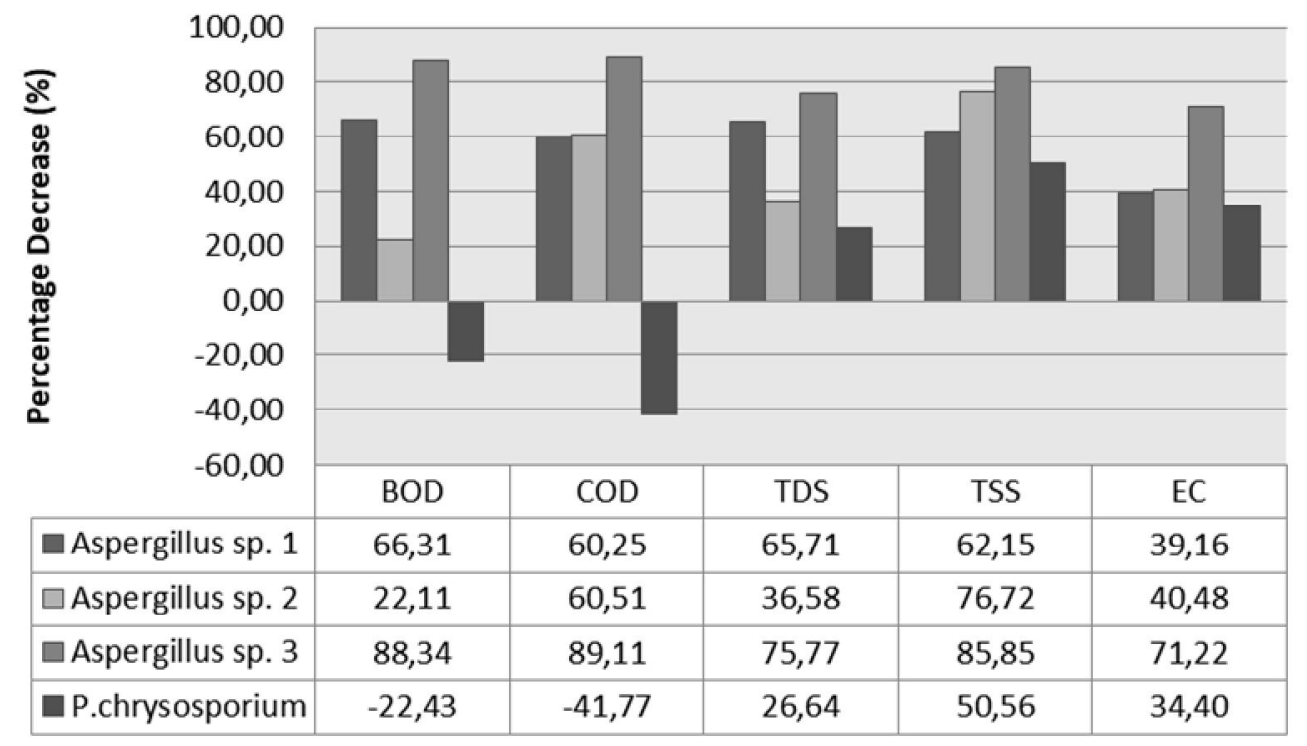

Figure 6. Percentage reduction of physiochemical properties by fungal isolates (percentage reduction in physiochemical properties)

The percentage BOD, COD, TDS, TSS and EC reduction by Aspergillus sp. 1, Aspergillus sp. 2, Aspergillus sp. 3 and P.chrysosporium is shown in Fig. 6.

In this study, Aspergillus sp. 3 also showed excellent pollutant reduction capabilities, and also showed the best resultsin thereduction of physiochemical properties. The effect of treatment on BOD, COD, TDS, TSS and $E C$ reduction was studied as a function of treatment by Aspergillus sp. 3, as shown in Figure 6. All the parameters decreased in the treated, as compared to the untreated, IB batik effluent. The results also show that Aspergillus sp. 3 was very effective inthe removal of BOD, COD, TDS, TSS and EC from the IB batik effluent. It can be seen in figure 6 that Aspergillus sp. 3 is appropriate for reducing the physiochemical properties in IB batik effluent, presenting superior BOD, COD, TSS, TDS and EC percentage reduction $(88.34 \%, 89.11 \%$, $75.77 \%, 85.85 \%$ and $71.22 \%$, respectively), when compared to P.chrysosporium isolate as the positive control (corresponding figures of $22.43 \%,-41.77 \%, 26.64 \%, 50.56 \%$ and $34.4 \%$ ) and the other types of Apergillus sp.

The reduction in BOD by Aspergillus sp. 3was $1470.68 \mathrm{mg} \mathrm{L}^{-1}$ (untreated effluent) to $171.48 \mathrm{mg} \mathrm{L}^{-1}$ (treated effluent) (Figure 1), with a mean removal efficiency of $88.34 \%$ (Figure 6). Similar results were reported by Kshirsagar (2013), who assessed the reduction in BOD and COD of domestic wastewater samples from the sewage wastewater treatment plant Bopodi in Pune city, India using the fungal isolates Aspergillus terreus, Aspergillus niger, Rhizopus 
nigricans, Rhizopus nigricans and Cunninghamella, which were isolated from the Mula river in Pune andefficiently utilized for remediation. Aspergillus terreus and Aspergillus niger showed excellent pollutant removal capabilities.

BOD and COD removal efficiency was a similar manner as dye removal efficiency. Reduction in COD and BOD is indicated by a degradation of the dye in the simulated effluent as a result ofthe activity of the fungal system, making these fungal strains a promising starter for the in situ bioremediation process of textile effluent treatment (Kshirsagar, 2013). The color removal of IB batik effluent is related to the decrease in the parameter value of the quality standard. This occurs because of biosorption and biodegradation mechanisms. Knapp and Newby (1995) state that biosorption is the primary dye removal mechanism. This research is line with the previous study of Aksu and Tezer (2000), who reported that the biosorption mechanism using free cell fungal was linked to the electrostatic pull between the positively charged cell wall components and the negatively charged dyes. Another description of the biosorption mechanism for binding dyes is given by Kurniasih (2017), who states that theactivity mechanism occurs from the interaction between a cationic chain material and negativity of macromolecules on the surface of the fungal cell. In this case, macromolecules on the surface of the fungal cell caused interaction between the dye cationic chain and negativity capacity on the fungal cell surface. Gnanadoss et al. (2013) are ofthe same opinion, stating thatthe cell wall plays a vital role in dye adsorption. Increased cell biosorption can be a result ofthe higher surface area available for the dye to bind.

The subsequent mechanism after biosorption is biodegradation. These observations are in line with the findings of Balan and Monteiro (2001), who reported on the removal of indigo dye by absorption and extracellular degradation of fungal. Reductions in BOD and COD levels, along with color removal, prove that the mechanisms of biodecolorization and biodegradation occurred simultaneously (Andleeb et al., 2012). Fujii et al. (1988) reported on the role of enzymes from $A$. terreusin catalyzing the vat dye ring cleavage reaction.

The percentage reduction in the case of Aspergillus spp. indigenous fungus was up to $22 \%$,compared to $-22.425 \%$ and $-41.7722 \%$ by P.chrysosporium. It has been proven that the indigenous fungi were better than the positive control,with a great ability to degrade amounts of the xenobiotic compound.

On the other hand, it has been observed that P.chrysosporium achieved the lowest percentage reduction inBOD and COD. This may mean that it secretes certain organic materials in its metabolism during the incubation time, which increases the amount of organic material and thus increases the BOD and COD values.

The TDS, TSS concentration and EC value of the P.chrysosporium were lower than the negative control, but the values of $B O D$ and COD were higher. The increased BOD and COD valueswere due to the performance of the P.chrysosporium, which was not optimum to produce enzyme. This indicates that the isolate can only partially break down bonds of organic compounds in IB batik effluent. Otherwise, it has been shown that the fungal isolates are more effective than P.chrysosporium.

\section{Conclusion}

It is concluded that all the fungal isolates from the dye effluent soil and batik effluent show promise for effluent treatment. Using such indigenous fungal isolates, water quality parameters can be effectively reduced from the IB batik effluent. The values of BOD after treatment using Aspergillus sp. 1, Aspergillus sp. 2 and Aspergillus sp. 3 were 22.1, 66.31 and 88.34 respectively. Other parameters, such as COD, TSS, TDS and EC, showed high levels of reduction, which decreased when using indigenous fungal isolates. Aspergillus sp. 3 is the best isolate, showing the highest percentage reduction inBOD, COD, TSS, TDS, and EC. The comparison isolate, $P$. chrysosporium, had the lowest value for all the parameters. The indigenous fungal isolate Apergillus spp. was very effective in the efficient treatment of the IB batik effluent and has potential for future analysis in the treatment of all types of batik effluent.

\section{Acknowledgements}

The authors are grateful to the Directorate of Research and Community Service, Ministry of Research, Technology and Higher Education (Kemenristek Dikti), Indonesia through the Doctoral Dissertation Research scheme for funding the research facilities to carry out this study.

\section{References}

Aksu,Z. and Tezer,S. 2000. Equilibrium and kinetic modelling of biosorption of 
Remazol Black B by Rhizopus arrhizus in a batch system: effect of temperature. Process Biochemistry 36, 431-439.

Ambrosio, S.T. and Campos-Takaki, G.M., 2004. Decolorization of reactive azo dyes by Cunninghamella elegans UCP 542 under co-metabolic conditions. Bioresource Technology 91, 69-75.

Andleeb, S., Atiq, N., Robson, G.D. and Ahmed, S., 2012. An investigation of anthraquinone dye biodegradation by immobilized Aspergillus flavus in fluidized bed bioreactor. Environmental Science and Pollution Research 19, 1728-1737.

Arimoro, F.O., Ikomi, R.B. and Iwegbue, C.M., 2007. Ecology and abundance of oligochaetes as indicators of organic pollution in an urban stream in southern Nigeria. Pakistan journal of biological sciences: PJBS 10, 446-453.

Aryani, Y.,Sunarto, T. Widiyani., 2004. Toksisitas Akut Limbah Cair Pabrik Batik CV. Giyant Santoso Surakarta dan Efek Sublethalnya terhadap Struktur Mikroanatomi Branchia dan Hepar Ikan Nila (Oreochromis niloticus T.). BioSMART 6.

Budiyono, Sudibyo, W., Herlina, S., Handayani, S., Parjiyah, Pudiastuti, W., Syamsudin, Irawati, Parjiyati, Palupi, D.S. 2008. [Textile Craft for Vocational high School Volume 1]. Direktorat Pembinaan Sekolah Menengah Kejuruan, Direktorat Jenderal Manajemen Pendidi

Departemen Pendidikan Nasional, Jakarta.

Cameron, M.D., Timofeevski, S. and Aust, S.D., 2000. Enzymology of Phanerochaete chrysosporium with respect to the degradation of recalcitrant compounds and xenobiotics. Applied Microbiology and Biotechnology 54, 751-758.

Balan, D.S., and R.T. Monteiro. 2001. Decolorization of textile indigo dye by ligninolytic fungi. J Biotechnol 89, 141-145.

cKinetics, 2018. Direct printing with Indigosol colours.

http://www.handprintingguiderajasthan.i n. May 3, 2018

Eichlerová, I., Homolka, L. and Nerud, F., 2006. Synthetic dye decolorization capacity of white rot fungus Dichomitus squalens. Bioresource Technology 97, 21532159.

Fajri, P.Y.N., 2013. [Spatial modeling for the location of wastewater treatment batik installation in Pekalongan, Central Java]. Thesis, Sekolah Pascasarjana Institut Pertanian Bogor, Bogor.

Fujii, I., Ebizuka, Y., Sankawa, U. 1988. A novel anthraquinone ring cleavage enzyme from Aspergillus terreus. J Biochem 103, 878-883.

Gnanadoss, J.J., Peeris, S.M. and Jebapriya, G.R., 2013. Biological enhanced absorption of synthetic dyes using oyster mushroom fungus Pleurotus ostreatus. Asian Journal of Environmental Biology Science 4, 637640.

Jagson Colorchem Ltd, 2011. Indigo Sol Vat .http://www.jagson.com/indigo-solvat.php. accessed 5/27/2016.

Kaushik, P. and Malik, A., 2009. Microbial decolourization of textile dyes through isolates obtained from contaminated sites. Journal of Scientific \& Industrial Research 68, 325-331.

Knapp,J.S. and Newby,P.S., Reece, L.P. 1995. Decolorization of dyes by wood-rotting basidiomycete fungi. Enzyme and Microbial Technology 17, 664-668.

Kshirsagar, A.D., 2013. Application of bioremediation process for wastewater treatment using aquatic fungi. Int. J. Curr. Res 5,1737-1739.

Kurniasih, M., Dewi, R.S., Purwati, P., Hermawan, D., and Aboul-Enein, H.Y., 2017. Synthesis, Characterization and Antifungal Activity of N-Methyl Chitosan and Its Application on the Gauze, Current Bioactive Compounds 13, 1-10.

Kusumastuti, A. and Syamwil, R., 2014. The Recycle of Batik Wax: an Effort towards Environmental Friendly Process.

Metcalf \& Eddy, Inc. 1991. Wastewater Engineering: Treatment, Disposal and Reuse, 3th ed., McGraw-Hill, New York

Nindita, V., Purwanto \& Sutrisnanto, D., 2012. [Evaluation of Eco-Efficiency Implementation in One Small Medium Enterprises Batik in Pekalongan Regency]. Jurnal Riset Teknologi Pencegahan Pencemaran Industri 2, 8291. 
Paradise, P.R. 1999. Trademark counterfeiting, product piracy, and the billion dollar threat to the U.S. economy. Greenwood Publishing Group, Westport, USA. pp. 73-76.

Rashidi, H.R., Sulaiman, N.N. and Hashim, N.A., 2012. Batik industry synthetic wastewater treatment using nanofiltration membrane. Procedia Engineering 44, 2010-2012.

Rhodes, C.J., 2014. Mycoremediation (bioremediation with fungi)-growing mushrooms to clean the earth. Chemical Speciation \& Bioavailability 26, 196-198.

Rochma, N. and Titah, H.S., 2017. [Decrease of BOD and COD of Batik Industrial Liquid Waste Using Activated Carbon Through Batch Adsorption Process]. Jurnal Teknik ITS 6, F325-F329.

Rita de Cássia, M., de Barros Gomes, E., Pereira Jr, N., Marin-Morales, M.A., Machado, K.M.G. and de Gusmão, N.B., 2013. Biotreatment of textile effluent in static bioreactor by Curvularia lunata URM 6179 and Phanerochaete chrysosporium URM 6181. Bioresource technologz 142, 361-367.

Ryu, B. H. \& Weon, Y. D. 1992. Decolorization of azo dyes by Aspergillus sojae B-10. J. Microbiol. Biotechnol 2, 215-219.

Salar, R.K., Kumar, J. and Kumar, S., 2012. Isolation and Evaluation of Fungal Strains from Textile Effluent Disposal Sites for Decolorization of Various Azo Dyes. Terrestrial and Aquatic Environmental Toxicology 6, 96-99.

Sankaran, S., Khanal, S.K., Jasti, N., Jin, B., Pometto III, A.L. and Van Leeuwen, J.H., 2010. Use of filamentous fungi for wastewater treatment and production of high value fungal byproducts: a review. Critical reviews in environmental science and technology 40, 400-449.

Schrott, W. 2001. Denim wieder im blickpunt der textile industrie. Melliand Textilber 82, 331-337.

Shahid, A., Singh, J., Bisht, S., Teotia, P. and Kumar, V., 2013. Biodegradation of Textile Dyes by Fungi Isolated from North Indian Field Soil. Environment Asia 6.
Spadaro, J.T., Gold, M.H., \& Renganathan, V.. 1992. Degradation of azo dyes by thelignin-degrading fungus Phanerochaete chrysosporium. Appl. Environ. Microbiol 58, 2397-2401.

Sunarto, 2008. [Dyeing and Printing Technology. Volume 3]. Departemen Pendidikan Nasional, Jakarta : 425445.

Velz, C.J., 1984. Applied stream sanitation. $2^{\text {nd }}$ End. Wiley Interscience. New York. 